\title{
ISSN: 2638-1974

\section{Oil and Gas Industry of Russia: Sanctions as an impetus to development}

\author{
Liudmila Berezhnaia ${ }^{*}$
}

*Associate Professor, PhD of Economics, Gubkin Russian State University of Oil and Gas (National Research University), Financial Management Department, Moscow, Russia

\section{Article Info}

*Corresponding author:
Liudmila Berezhnaia
Associate Professor
PhD of Economics
Gubkin Russian State University of Oil and
Gas (National Research University)
Financial Management Department
Moscow, Russia
E-mail: berezhnayali@ya.ru

Received: July 14, 2017

Accepted: July 22, 2017

Published: July 28, 2017

Citation: Berezhnaia L. Oil and Gas Industry of Russia: Sanctions as an impetus to development. Int J Petrochem Res. 2017; 1(2): 87-91.

doi: $10.18689 / \mathrm{ijpr}-1000115$

Copyright: (c) 2017 The Author(s). This work is licensed under a Creative Commons Attribution 4.0 International License, which permits unrestricted use, distribution, and reproduction in any medium, provided the original work is properly cited.

Published by Madridge Publishers
Keywords: Oil and Gas; hydrocarbon; Chemical products

Russia is a country with a rich base of mineral resources. Proven recoverable oil reserves are estimated as 11 billion tons [1]. Russia retains one of the first places in the world in oil production. Overall oil production as of 2016 was equal to 548 million tons. The position of Russia as the largest exporter remains unchanged. In 2016, export of oil amounted to 254.8 million tons, with 284 million tons of processing [2].

The share of the five largest Russian oil companies ("Rosneft", "LUKOIL", "Gazprom Neft", "Tatneft", and "Surgutneftegaz") accounts for over $80 \%$ of oil production in the country.

Russian has proven natural gas reserves of 48.7 trillion cubic meters. It is about $25 \%$ of total world reserves [3]. The gas industry employs about 256 companies, including:

- 140 are independent production companies

- 100 are included in the structure of vertically integrated oil companies

- 16 make part of "Gazprom". Their share is more than $75 \%$ of gas production in the country.

Overall gas production as of 2016 was 640 billion cubic meters, including 74.3 billion cubic meters of processing and 198.7 trill. cubic meters of export in totaling to $\$ 31.374$ billion [4]. At present, key consumers of Russian oil and gas are the countries of Western Europe.

As of today, oil and gas companies are one of the main sources of replenishment for the country. Their share in revenues of the Federal budget for a long time has been about 50\%. However, following the collapse of prices in mid-2014, the share of oil and gas sector in the formation of revenues of the Federal budget reduced from $51.3 \%$ to $36 \%$ under the influence of falling prices on hydrocarbon raw materials and processed products, and due to the intensification of activity of the enterprises of the non-oil sector and the service [5].

It should be noted that in the consolidated budget, which also includes regional budgets and revenues of the insurance funds, the share of oil revenues is almost twice lower and for the period 2014-2016 it decreased from $27.8 \%$ to 17.2 [6]. This suggests that the Russian economy is sufficiently diversified and is able to withstand low prices for hydrocarbons at the expense of other sources of income.

The core problem is hidden in the fact that production of oil and gas companies is almost the only source of replenishment of currency reserves of the country. The oil and gas sector accounts for more than $80 \%$ of foreign exchange earnings in the country's budget.

The oil and gas industry will play a significant role in shaping the country's budget, given the presence of huge hydrocarbon reserves in Russia and the relentless demand of the world community. Therefore, the state's attention to this type of activity continues unabated. 
The aim of this work is to analyze the actions taken by the Russian government and oil companies, which in difficult economic conditions provide the vital functions of the oil and gas industry. With the fall in oil prices and imposition of economic and technological sanctions against Russia, there emerged difficulties, which involve both businesses and government.

\section{What can the state do?}

The main lever of state influence on the activities of commercial enterprises is tax regulation. The state, depending on the objectives of the oil industry, adjusts tax legislation, directing the activities of the companies in the right way.

The principal taxes payable by oil and gas sector are a Tax on Mineral Extraction (MET) and Customs duty. The tax system in oil industry is specific and structured in such a way that allows to adjust the amount of tax deductions depending on the price of oil (Fig.1)

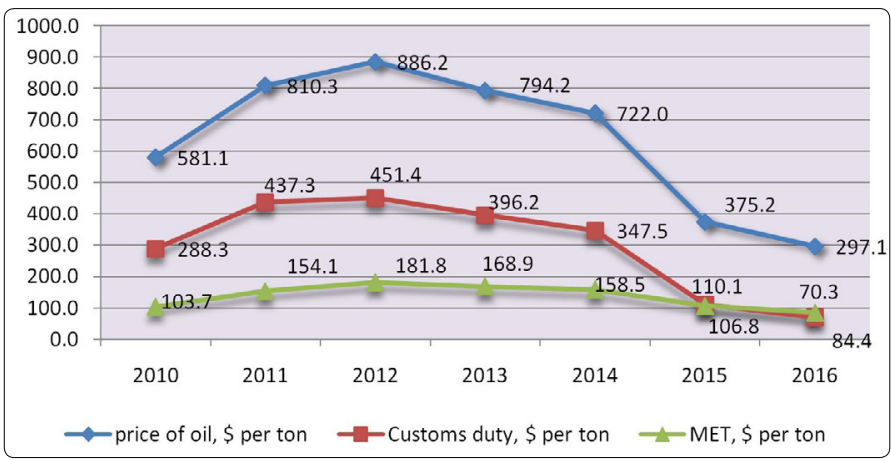

Figure 1. Dependence of Customs duty and Mineral Extraction Tax on oil price dynamics

While oil prices decline, the tax burden of enterprises decreases, with increasing oil prices it goes up as well. At a price below $\$ 15 /$ bar., Customs duty and Tax on Mineral Extraction becomes zero. Such a flexible approach allows to establish mutually beneficial relationships between the main participants in the oil business: the state, owner of the mineral resources, and oil companies.

What is tax reform? During the last few years, Russia has carried out tax reforms in the oil sector. The essence of tax reform is the decrease in Customs duty while increasing the Mineral Extraction Tax. We can observe a maneuver between the two fundamental taxes.

There are three stages of the tax maneuver:

Stage 1 (2012-2013). The task was the fight against the "black oil" scheme. Therefore, the rate of state of export duty on crude oil was reduced from 65 to $60 \%$. Companies directed additional foreign currency funds to finance the modernization of the refinery by reducing customs duties.

Stage 2 was planned for 2014 -2016 for the implementation of the tasks, and it aimed to provide future gradual reduction of export duty from $60 \%$ to $55 \%$. Nevertheless, since the oil prices fell in the middle of 2014, Russian government had to move to Stage 3 in 2015-2017, executing the so-called "Big Tax Maneuver"
The goal of Stage 3 is to maximize foreign exchange earnings in the companies under the limited opportunities to borrow funds on global financial markets due to the imposition of economic sanctions. As a result, for the period 2015-2017 a sharp decrease in Customs duty rate from 59\% in 2014 to $42 \%$ in 2015 was foreseen, and in the two coming years it had to constitute $36 \%$ and $30 \%$ [7]. Figure 2 shows the dynamics of rates of customs duties. Implementation of actions of Stage 3 allowed the government to reduce sharply its share in foreign exchange earnings, and thereby to create favorable conditions for business.

What is the benefit received from the tax maneuver? As shown by the calculations for two years of the new tax regulator, extra income of companies is estimated at 12.5 billion dollars. The «price of maneuver» for the budget is the reduction of foreign exchange earnings from oil and gas business by $20 \%$.

At the same time, the government increases Mineral Extraction Tax, calculated in rubles, from 493 rubles per ton in 2014 to 919 rubles per ton in 2017 [7]. Figure 3 shows the dynamics of rates of tax on extraction of mineral.

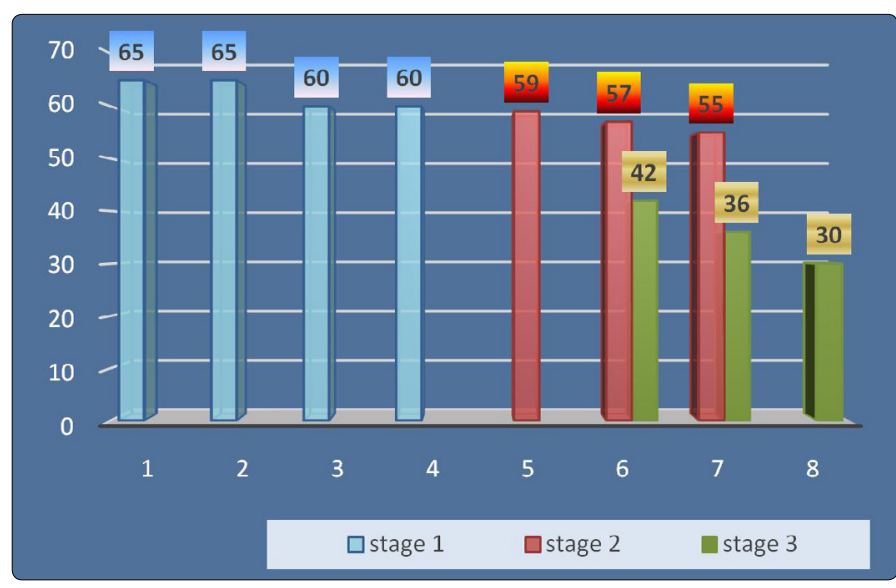

Figure 2: Dynamics of Customs duty rates, \%

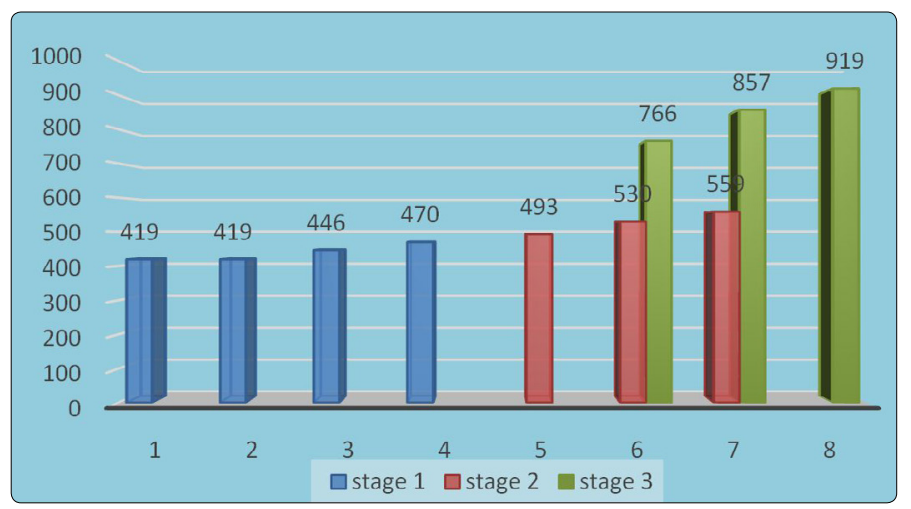

Figure 3: Dynamics of Mineral Extraction Tax rates, rub.per ton

Moreover, simultaneously with the fall in oil prices, the government has implemented a devaluation of the ruble. The Central Bank of Russia introduces almost a parity between changes in oil prices and the exchange rate of the ruble against the U.S. dollar.

As a result, following the decline in oil prices and, accordingly, foreign exchange earnings of companies, the dollar has increased. Figure 4 shows the trend of ruble and oil prices changes. The lower oil price is, the weaker the ruble is. 


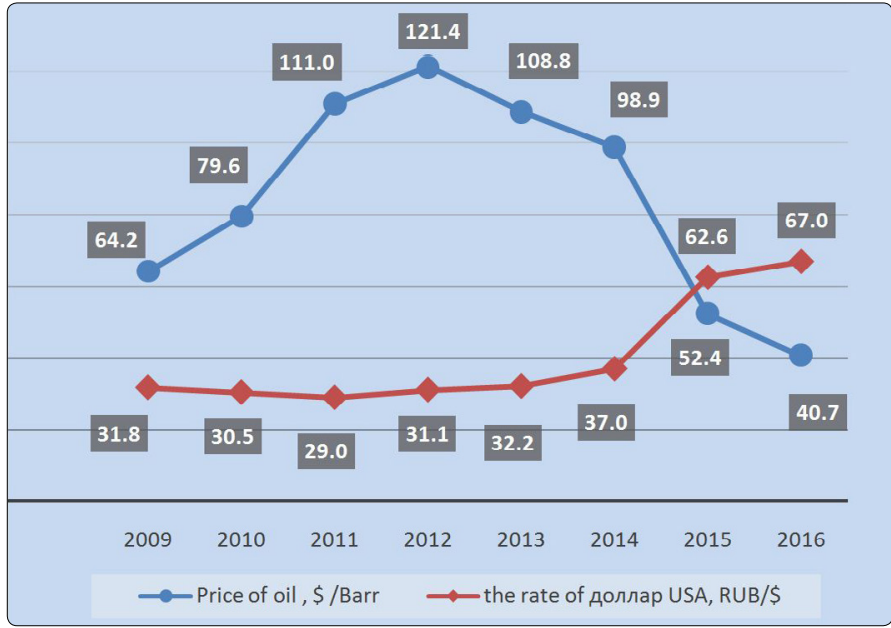

Figure 4. Dependence of the ruble on the oil price

What was the Russian benefit from the devaluation of the ruble? Conversion of foreign currency revenues into rubles has allowed increasing funds from enterprises and state in 1.8 times. As a result, the government by increasing the amount of money corrects the balance of payments of Russia. In addition, the increase of the ruble mass allows companies to maintain their production capacity and to continue to implement the already launched projects. Additional benefits from the conversion of the ruble companies received upon payment of the MET - the tax the state increased during the implementation of the tax maneuver.

What is the benefit received from the tax maneuver? On the one hand, by lowering export taxes reduced deductions to the state budget of revenues obtained from exports, on the other - an increasing share of foreign exchange for business. These additional funds, the companies aimed at the solution of current tasks, including the completion of a previously initiated process of modernization of the refinery. At the same time the missing part of the Federal budget revenues to some extent offsets the second tax, namely, increased almost 1.7 times the tax on extraction of mineral resources.

Table 1 reflects the impact of regulatory actions by the state to ensure the functioning of oil companies in the crisis.

Table 1. Impact of regulatory actions by the state to ensure the functioning of oil companies in 2014-2016

\begin{tabular}{|c|c|c|c|c|c|}
\hline Year & $\begin{array}{c}\text { Price of oil, } \\
\$ / \text { bar }\end{array}$ & $\begin{array}{c}\text { Ruble exchange } \\
\text { rate, rub./\$ }\end{array}$ & $\begin{array}{c}\text { Price of oil, } \\
\text { rub./ton }\end{array}$ & $\begin{array}{c}\text { Taxes, } \\
\text { rub./ton }\end{array}$ & $\begin{array}{c}\text { Share of taxes in } \\
\text { the price, } \%\end{array}$ \\
\hline 2014 & 98,9 & 36.99 & 26706 & 18716 & 70,0 \\
\hline 2015 & 51,4 & 62.55 & 23470 & 13572 & 57,8 \\
\hline 2016 & 40,7 & 66.95 & 19894 & 10444 & 52,5 \\
\hline
\end{tabular}

While in fact the average price of 1 barrel of oil on the world market from 2014 to 2016 decreased in 2.43 times, in ruble terms the decline amounted to less than 1.4 times.

In addition, with declining oil prices, the tax burden on companies is reduced. So, in 2014, when the price of oil was at $\$ 100$ per barrel, with each ton of exported oil, the state has transferred $70 \%$ of revenue, while in the next two years, following the decline of prices, the state's share is reduced to 58 and $52 \%$.

Additionally, a great deal of influence on the oil and gas industry was rendered by tax incentives. Today fields that fall under the preferential ensure taxation the main growth of oil production. Easing the tax burden contributes to the development of small and medium-sized fields, fields with hard to recover reserves, new deposits in the East of the country, and allows cost-effective development of hydrocarbons in depleted fields. Preferential oil volume in 2016 exceeded 190 million tons, accounting for about 35\% of total production in Russia.

According to the experts at the Investment Bank Goldman Sachs, the return of the Russian oil and gas projects improves due to the favorable tax regime. "According to our estimates, a typical Russian oil field can generate positive cash flow, provided that the price of oil remains above $\$ 10$ per barrel", state the experts of the Bank [8].

However, there were still numerous challenges that Russian oil and gas industry faced with the imposition of the sanctions:

- Many of the projects associated with the need to attract large investments were suspended due to limited financial possibilities.

- Throughout exploration reduced, that threatened a total loss of exploration.

- A particular problem for the petroleum industry in Russia was the lack of its own technologies and equipment for oil production in complicated conditions. By the moment of the sanctions Imposition, the share of foreign equipment in the domestic oil and gas industry sector was estimated in the range of $80 \%$ [9].

- Currently enterprises rely mainly on domestic borrowing due to imposed sanctions. Investments coming from the global financial market are not significant.

\section{What are companies doing?}

Under the conditions of aggressive geopolitical situation, companies have a serious focus on internal improvements. Many domestic plants, scientific organizations offer their latest innovative developments, which are not only not inferior to the world analogues, but in many performance characteristics superior to them.

Import substitution is a priority in the development of oil and gas corporations. Import substitution is not only the creation of new equipment and technologies, it is an opportunity for domestic producers to compete with Western companies.

Innovation has allowed «Gasport» to go back from the supply of large diameter pipes German and Japanese manufacturers, according to the Russian Association of manufacturers of tubes.

Chemical products continue to displace imports from the country. To the greatest extent import substitution has occurred in the line of pharmaceutical products, which switched to an international standard of production and quality control of medicines. 
Analysts of Bloomberg acknowledged that the food embargo on imported products has become a driver for the development of Russian agriculture, the country turns into a "food colossus". Thus, recognizes the edition, import substitution has made Russia the largest exporter of wheat, leaving behind United States of America, which already brings a much higher income country than the production of "black gold" or even the sale of weapons [10].

The substitution gave new jobs to Russian enterprises and opened up great prospects for industry and agriculture. It is not surprising that unemployment in Russia is now at a very low level of 5.2\% [11].

Companies continue to implement the earlier projects, and at the same time to develop new ones. They upgraded the refinery to produce gasoline, the quality of which meets the world standards. In the Russian North oil shipping through the commissioned marine terminal "Gate of the Arctic" was launched. It is a unique construction: oil shipment through the Arctic terminal is carried out all year-round. The terminal may operate at a temperature of 50 degrees Celsius below zero. The $100 \mathrm{~km}$ pipeline connects the deposit and the terminal.

Oil and gas companies continue exploration and development of hydrocarbon reserves in the Arctic. At present, more than $90 \%$ of gas and about $10 \%$ of oil are provided by the fields in the Russian sector of the Arctic [12].

PJSC "Gazprom" signed a major contract for the construction of installations for the processing of arctic heavy hydrocarbon fields in Western Siberia On the territory of the Tyumen region there are large investment projects in the field of refinery: Antipinsky oil refinery and the Tobolsk site SIBUR.

Companies switch from production of crude oil to its processing and obtaining the finished product with the aim of increasing the profitability of the industry.

Eastern regions played an important role in stabilizing the oil industry, where there is an active development of oil reserves at new fields. Oil production from new fields in Eastern Siberia amounted in 2016 to 54 million tones.

The construction of transport infrastructure turned out to be a powerful incentive to the development of the resource base and of oil production in Eastern Siberia and the Far East. Infrastructure projects include, for instance, the trunk pipeline Eastern Siberia-Pacific Ocean (ESPO) and the specialized sea oil port in Kozmino, the network lead and the connecting pipelines from fields in Eastern Siberia to the ESPO pipeline, as well as from fields of Sakhalin island to the port of De Kastri.

The presence of significant resource potential, transport network and proximity to fast-growing Asia-Pacific markets determine investment attractiveness of Eastern regions of Russia. 'Rosneft' has meaningful points of interest in Eastern Siberia and the Far East. To be more specific, it owns the license to develop the largest deposits of Vankor and Verkhnechonsk. In the Far East the first turn of shipbuilding complex "Zvezda" was put into operation, which should provide an impetus for economic development of the whole Far Eastern region. The company is actively working on the project "Far East Liquid natural gas (LNG)", believing it to be very promising.

"Surgutneftegaz" company has 24 licenses in Eastern Siberia for areas in Yakutia, Irkutsk region and Krasnoyarsk region. LUKOIL company outbid "Rosneft" and received the first license for the subsoil use in Eastern Siberia, which opens the new prospects to the company.

Gazprom rapidly carries out construction of the pipeline "Power of Siberia" for gas supplies from Russia to China. By the end of 2017, it is planned to increase the length of the pipeline up to $1100 \mathrm{~km}$ and approach the border with China. The Asia-Pacific region is the Gazprom's traditional market for the supply of liquefied natural gas. In 2016, 2.8 million tons of LNG were sold to the Asian market.

Foreign investors are interested in the Eastern Siberia and the Far East that was confirmed by their attention to the Eastern economic forum (WEF). The previous Forum, held in 2016, gathered 4-6 thousand representatives of business, experts and scientific community representatives from 56 countries. There were signed contracts to the amount of 1.63 billion rubles. In September 2017, in the capital of Primorye Vladivostok, on Russky island, there will be held the Third International Economic Forum, where the presence of highlevel governmental officials of China, Japan, South Korea, and Vietnam is planned. In addition to the Pacific Rim countries, an application for participation was received from Australia, Canada and the United States of America, and European countries, including the UK, Germany and others [13].

\section{Lessons learned}

The past few years tested the strength of the Russian economy, allowing it to feel its dependence on the commodity sector and an unacceptable backlog in many areas of scientific and technological progress of the world level.

The country has, given the realities of the present day, to learn how to counter geopolitical threats to real actions aimed at stimulating growth and ensuring long-term sustainability of the national economy.

Despite the fact that the Russian budget still depends largely on oil and gas revenues, it is necessary to establish changes in the structure of its content. Russia managed to establish mechanisms to limit public spending and to improve the efficiency of the tax system that allows every year to increase the percentage of income not related to the sale of hydrocarbons, confirm analysts of Forbes.

For the second year in a row, Russia maintains the leading positions in the world oil production. In 2016, the volume of oil with gas condensate reached 547.5 million tons, renewing the record of the previous year. Gas production in 2016 increased by $0.7 \%$ and amounted to 640.007 billion cubic meters. Volumes of geological exploration and production drilling are growing. Capital investments in the oil and gas sector are constantly increasing, and in 2016, investment increased by $12 \%$ and amounted to 1200 billion rubles.

In order to avoid stagnation and promote further development, it is crucial that Russia perceives sanctions as an impulse to the revival of its oil and gas industry. 


\section{References}

1. Proven oil Reserves in the world. World Factbook. Accessed February 5 , 2017.

2. On the state of the oil market in 2016. Accessed April 7, 2017.

3. The proven gas reserves of countries in 2016. Accessed February 5, 2017

4. Gas production in Russia in 2016. Accessed April 24, 2017.

5. On execution of the Federal budget for January-December 2016. Accessed June, 2017.

6. Brief information on execution of the consolidated budget of the Russian Federation. Accessed 30 June, 2017.

7. The Law of the Russian Federation from 24.11.2014 № 366 -Ф3 "On amendments to part two of the Tax code of the Russian Federation and certain legislative acts of the Russian Federation". Accessed 19 January, 2015.
8. Goldman Sachs: Russian field on average is profitable if the price is above \$10 per barrel. Accessed September 15, 2016.

9. The share of imported equipment in the oil and gas industry. Accessed December 22, 2014.

10. Bloomberg amazed: agriculture of the Russian Federation grows on predamage by leaps and bounds. Accessed January 11, 2017.

11. The levels of unemployment in 2016. Accessed July 01, 2017.

12. Kontorovich AE. Oil and gas in the Russian Arctic: the history of development in the twentieth century, resources, strategy for the twenty-first century. Science first hand. Our Arctic. 2015; 41(N2): 46-66.

13. Korzinkina S. Delegations from 24 countries have confirmed their participation in the WEF-2017. Accessed July 12, 2017. 